\title{
Rancang Bangun Sistem Pemantauan Lingkungan Laut Pendukung Aplikasi Marikultur Cerdas K1000 dengan Protokol MQTT
}

\section{Design of Marine Environmental Monitoring System to Support the K1000 Smart Mariculture Application Using the MQTT Protocol}

\author{
Irman Hermadi $^{1 *}$, Aji Fajar Nugraha ${ }^{1}$, Sri Wahjuni ${ }^{1}$, Irzal Effendi ${ }^{2}$, Auzi Asfarian $^{1}$
}

\begin{abstract}
Abstrak
Kelompok Sea Farming merupakan sebuah kelompok masyarakat yang menerapkan kegiatan marikultur. Kelompok Sea Farming sangat membutuhkan sistem yang dapat memantau lingkungan laut. Variabel lingkungan laut yang mereka butuhkan ialah suhu dan kelembaban udara, suhu air laut dan kadar oksigen terlarut. Pemantau lingkungan laut memiliki tugas untuk menentukan waktu pencucian ikan berdasarkan perubahan suhu, kelembaban udara, suhu air, dan kadar oksigen terlarut. Penelitian ini dilakukan untuk merancang dan membangun arsitektur internet of things (IoT) menggunakan protokol the message queuing telemetry transport (MQTT) untuk memantau lingkungan laut pada keramba dengan menggunakan sensor yang terhubung dengan internet dan ditampilkan pada aplikasi secara waktu nyata. Sistem yang dibuat diharapkan dapat membantu nelayan dalam memantau dan menyimpan data dari perubahan lingkungan laut serta mendukung pengembangan aplikasi Marikultur Cerdas Kepulauan Seribu (K1000). Hasil Penelitian ini telah berhasil dalam merancang dan membangun sistem pemantauan lingkungan laut dengan arsitektur IoT, mulai dari pengambilan data dari sensor hingga pengiriman data masuk ke basis data dan menampilkannya sebagai grafik. Selain itu, keseluruhan pengujian kunci dan kebijakan IoT menunjukkan komunikasi data IoT menggunakan layanan AWS terjamin keamanannya. Dengan delay 0.005 detik, paket loss $0 \%$, dan overhead sebesar $36.8 \%$.
\end{abstract}

Kata Kunci: internet of things, marikultur, MQTT, pemantauan, pencucian ikan.

\begin{abstract}
Sea Farming Group is a community group that implements mariculture activities. The Sea Farming group really needs a system that can access the marine environment. Marine environment variables that regulate air temperature and humidity, sea air temperature and dissolved oxygen levels. Marine environment monitors have the task of determining the washing time of fish based on changes in temperature, air humidity, air temperature, and dissolved oxygen levels. We conduct this research to design and build an internet of things (IoT) architecture using the message queuing telemetry transport (MQTT) protocol to study the marine environment in cages using sensors connected to the internet and code in real-time applications. The system created is expected to help fishers manage and store data from changes in the marine environment and support the Thousand Islands Smart Mariculture application (K1000). The results of this study have been successful in building and building a marine environmental system with IoT architecture, starting from taking data from sensors to sending data into the database and displaying it as a graphic. In addition, the total key testing and IoT policies show that IoT data communication using AWS is guaranteed. With a delay of 0.005 seconds, $0 \%$ packet loss, and $36.8 \%$ overhead.
\end{abstract}

Keywords: fish washing, mariculture, MQTT, monitoring, internet of things.

\section{PENDAHULUAN}

Maritime culture (marikultur) adalah istilah yang digunakan ketika merujuk pada produksi spesies laut oleh manusia. Istilah yang lebih luas disebut akuakultur, istilah ini

\footnotetext{
${ }^{1}$ Departemen Ilmu Komputer, FMIPA, Institut Pertanian Bogor.

${ }^{2}$ Departemen Budidaya Perairan, Fakultas Perikanan, Institut Pertanian Bogor

*Penulis Korespondensi: Tel/Faks: 0251-8625584; Surel: irmanhermadi@ apps.ipb.ac.id
} 
digunakan untuk menggambarkan semua jenis produksi spesies air, baik air laut dan air tawar. Contoh dari maritim kultur yaitu penambakan ikan laut, yang meliputi ikan kecil, kerangkerangan, udang-udangan dan rumput laut (Anderson 2003). Salah satu lokasi di Indonesia yang menerapkan maritim kultur berada di Pulau Panggang, Kepulauan Seribu. Di kepulauan tersebut terdapat kelompok nelayan yang bernama Sea Farming. Sea Farming merupakan kegiatan memproduksi benih ikan. Benih ikan mungkin masih berukuran kurang dari ukuran pasar (edible size), sehingga perlu dilakukan pemeliharaan lanjutan dalam sistem marikultur, baik keramba jaring apung (KJA) maupun keramba jaring tancap (KJT) (Effendi 2005).

Ikan kerapu macan merupakan salah satu komoditas marikultur yang terdapat di Pulau Panggang, Kepulauan Seribu. Ikan kerapu macan merupakan salah satu ikan yang sangat sensitif bila terjadi perubahan lingkungan sehingga ikan mudah terkena penyakit. Dikarenakan parasit di dalam air akan tumbuh pada selang suhu yang lebar, yaitu antara $0-35^{\circ} \mathrm{C}$ (Budianto dan Chilmawati 2014). Menurut Suminto dan Hirayama (1996), nelayan harus mencuci ikan dengan air tawar untuk menghindari penyakit, namun nelayan sangat sulit menentukan waktu yang tepat untuk melakukan pencucian ikan. Waktu pencucian ikan dapat dilihat dari kondisi air laut, jika suhu air laut dingin dan tidak berarus maka ikan harus dicuci. Ikan harus dicuci karena pada kondisi suhu air laut dingin parasit akan berkembang dan memangsa ikan kerapu. Nelayan sudah memiliki alat untuk memantau lingkungan laut, namun data yang dihasilkan dari alat belum bisa dilihat secara real time dan disimpan secara manual. Nelayan membutuhkan pencatatan suhu dan kelembapan udara, suhu air laut dan kadar oksigen terlarut pada air laut. Berdasarkan permasalahan tersebut dikembangkanlah konsep internet of things (IoT) (Uckelmann 2011) untuk memantau kondisi lingkungan laut. Pemantauan digunakan untuk melihat informasi mengenai kondisi lingkungan laut yang dapat diakses secara daring dan waktu nyata sehingga nelayan dapat menentukan waktu yang tepat untuk melakukan pencucian ikan.

Data dari sistem IoT akan dipakai sebagai pendukung aplikasi Nelayan Cerdas Kepulauan Seribu (K1000) sehingga nelayan dapat memantau kondisi lingkungan laut di sekitar keramba yang mereka miliki dari melalui aplikasi. Untuk pengukuran kadar oksigen terlarut tidak dilakukan dengan alat sesungguhnya tetapi menggunakan simulasi nilai acak dengan batasan nilai kadar oksigen normal pada air laut. Menurut Sutamihardja (1987), kadar oksigen di perairan laut yang normal berkisar antara 5.7-8.5 mg/l. Protokol yang digunakan untuk pengiriman data adalah message queuing telemetry transport (MQTT). Salah satu penelitian menggunakan protokol MQTT pernah dilakukan oleh Mulyono dan Haviana (2018) untuk pemantauan suhu dan kelembaban pada laboratorium. Penelitian ini bertujuan untuk menganalisis kinerja dan keamanan protokol MQTT 3.5 sebagai protokol komunikasi pada arsitektur IoT dan membangun sistem pemantauan lingkungan budidaya ikan kerapu. Hasil dari penelitian ini diharapkan dapat membantu nelayan dapat memantau dan mencatat secara otomatis data dari lingkungan laut pada setiap harinya.

Ruang lingkup dari penelitian ini sebagai berikut: 1) variabel lingkungan yang dipantau adalah suhu air laut, oksigen terlarut, suhu udara dan kelembaban udara, 2) alat yang dibangun bersifat prototype, 3) nilai dissolved oxygen (DO) diambil dari data acak bukan dari sensor, 4) sistem komunikasi menggunakan protokol MQTT 3.5 dengan quality of service (QoS) 1. Akibat terbatasnya mobilitas akibat pandemi Covid-19, uji coba dilakukan pada tempat tinggal peneliti bukan di Pulau Panggang Kepulauan Seribu, serta lingkungan pengujian penelitian pada jaringan nirkabel wifi publik.

\section{METODE}

\section{Data Penelitian}

Data yang digunakan pada penelitian ini adalah data dalam format angka yang bersumber dari pengukuran sensor. Nilai yang diperoleh yaitu suhu udara, kelembaban udara, dan suhu air yang masing-masing diperoleh menggunakan sensor DHT21 dan suhu air DS18B20, sedangkan data oksigen terlarut sendiri dibangkitkan dengan simulasi pembangkitan data acak 
melalui mikrokontroler. Data yang dikumpulkan akan disimpan dalam basis data yang sudah tersedia pada aplikasi Marikultur Cerdas K1000.

\section{Tahapan Penelitian}

Penelitian ini dibagi menjadi lima tahap utama yaitu identifikasi masalah, studi literatur, perancangan arsitektur sistem, implementasi, integrasi perangkat keras dan lunak, serta pengujian dan evaluasi. Alur penelitian dapat dilihat pada Gambar 1.

\section{Analisis Kebutuhan}

Pada tahapan ini dilakukan analisis terhadap kebutuhan sistem. Pengumpulan data dalam tahap ini bisa melakukan sebuah penelitian, wawancara, atau studi literatur. Sistem analis akan menggali informasi sebanyak-banyaknya dari pengguna sehingga akan tercipta sebuah sistem yang bisa melakukan tugas-tugas yang diinginkan oleh pengguna tersebut. Pada tahapan ini didapatkan informasi permasalahan dengan melihat langsung kondisi lingkungan tempat penelitian.

\section{Perancangan Arsitektur Sistem}

Tahapan ini dilakukan untuk menggambarkan skema sistem komunikasi antar alat yang digunakan seperti pada Gambar 2. Gambar 2 merupakan skema sistem pengiriman data, mulai dari sensor mengirimkan data menggunakan sinyal GSM. Data dikirimkan dalam bentuk string dan dikirimkan menggunakan MQTT pada server Amazon Web Services (AWS). Kemudian, data dari server akan disimpan ke dalam basis data MySQL menggunakan application programming interface (API) NodeJS. Data yang telah disimpan pada basis data dapat dipakai untuk pengembangan aplikasi Marikultur Cerdas K1000. Gambar skema dari masing-masing sensor dapat dilihat pada blok diagram Gambar 3.

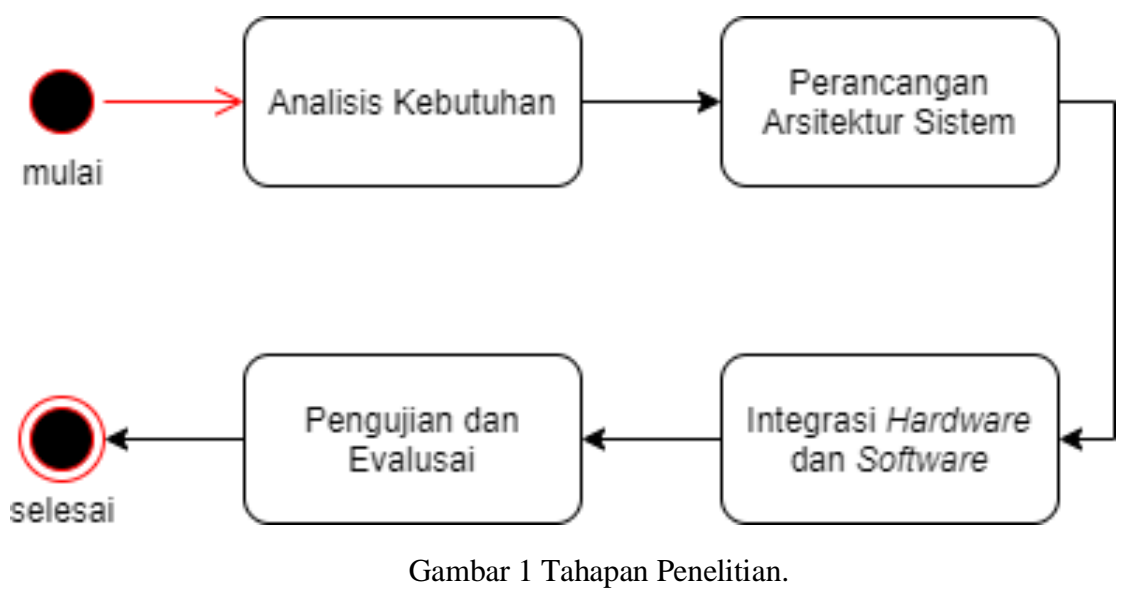

\section{Integrasi Perangkat Keras dan Perangkat Lunak}

Tahap ini merupakan tahap penggabungan antara program yang sudah dibuat dengan perangkat keras yang sudah dirakit. Hal yang harus diperhatikan dalam tahapan ini adalah kemampuan alat untuk menampung program dengan ukuran yang dibuat dan pustaka pemrograman yang digunakan.

\section{Pengujian}

Pada tahapan pengujian, alat pengukuran suhu udara, kelembaban udara, dan suhu air tidak dilakukan pada lingkungan laut sebenarnya, tetapi dipasang pada tempat tinggal peneliti. Pengujian tidak dilakukan pada lingkungan laut sebenarnya karena terjadinya pandemi sehingga peneliti tidak dapat pergi ke lingkungan laut sebenarnya. Suhu air laut dan air tawar tidak memiliki perbedaan dalam pengukuran. Menurut Nontji (2005) kadar garam pada air laut tidak mempengaruhi perbedaan suhu sedangkan yang mempengaruhi suhu air 
laut ialah kedalaman dan cahaya matahari, sehingga alat pengukur suhu air dapat digunakan untuk mengukur kedua jenis air tersebut. Skema sistem pengujian memiliki sedikit perbedaan dibandingkan dengan skema sistem IoT yang dirancang. Skema sistem dapat dilihat pada Gambar 4a. Gambar peletakan alat dapat dilihat pada Gambar 4b dan Gambar 4c.

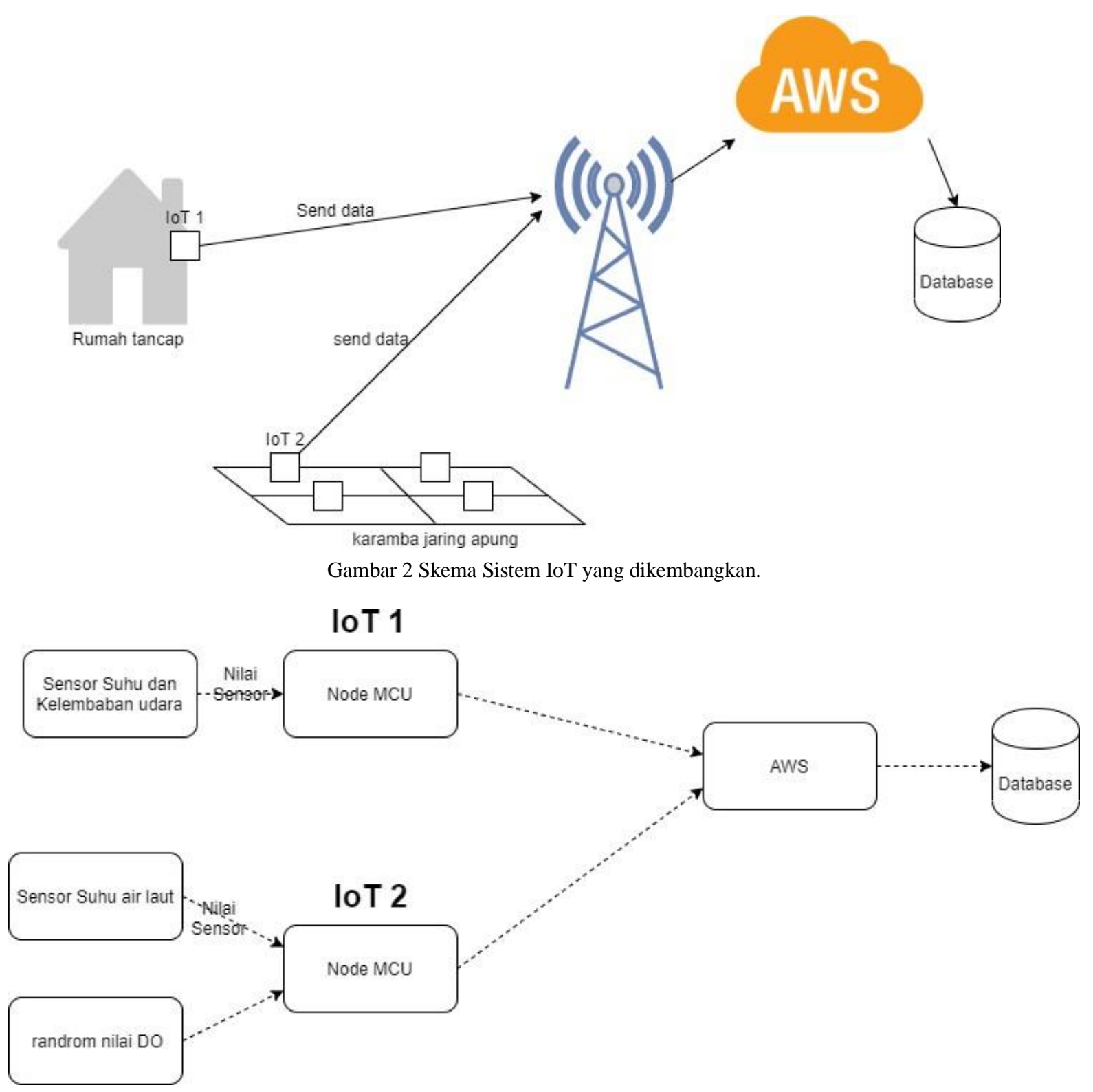

Gambar 3 Skema perangkat keras.

Tahapan pengujian dibagi menjadi dua bagian yaitu uji keamanan sistem komunikasi jaringan dan uji kinerja fungsi protokol MQTT. Pengujian keamanan jaringan protokol MQTT dilakukan dengan menggunakan metode black-box. Pengujian dilakukan dengan menggunakan sertifikat, kunci pribadi, dan topik pesan. Pengujian ini bertujuan untuk menjamin integritas dan autentikasi data. Pengujian kinerja suatu protokol dapat dilihat dari beberapa aspek yaitu protocol delay, packet loss, dan protocol overhead. Protokol yang diuji adalah MQTT yang dienkripsi dengan TLSv 1.2. Pengujian menggunakan perangkat WireShark untuk menyaring protokol MQTT yang sudah dienkripsi dengan TLSv 1.2. Skema pengujian menggunakan WireShark dapat dilihat pada Gambar 5. 


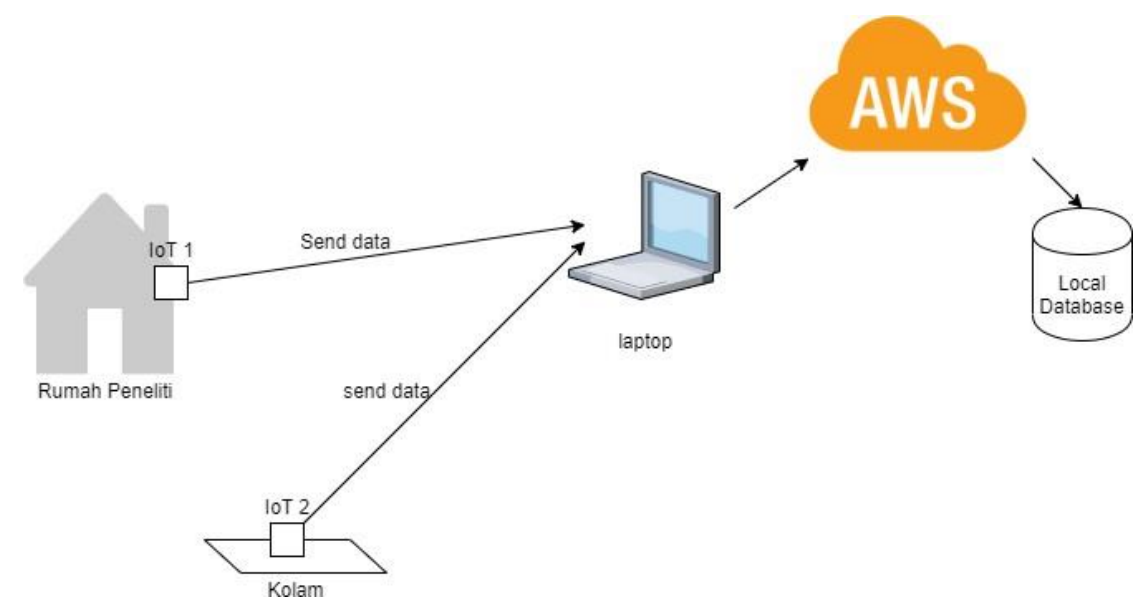

(a) Skema sistem untuk pengujian.

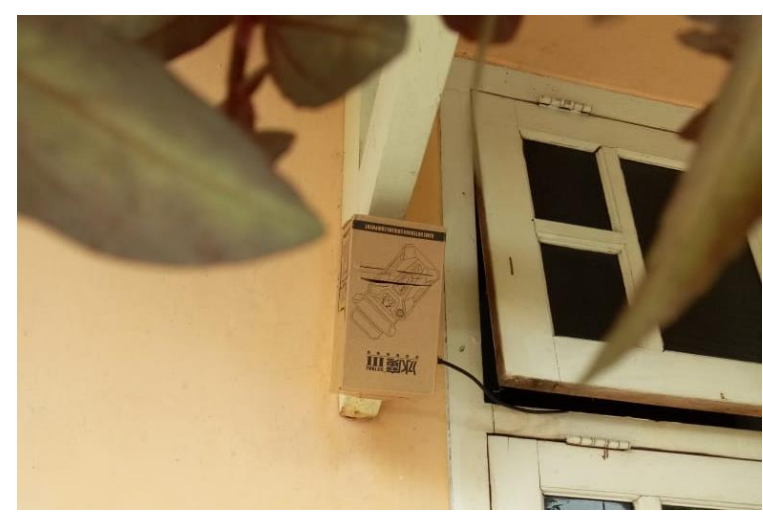

(b) Lokasi peletakan alat pada ujicoba suhu dan kelembaban udara.

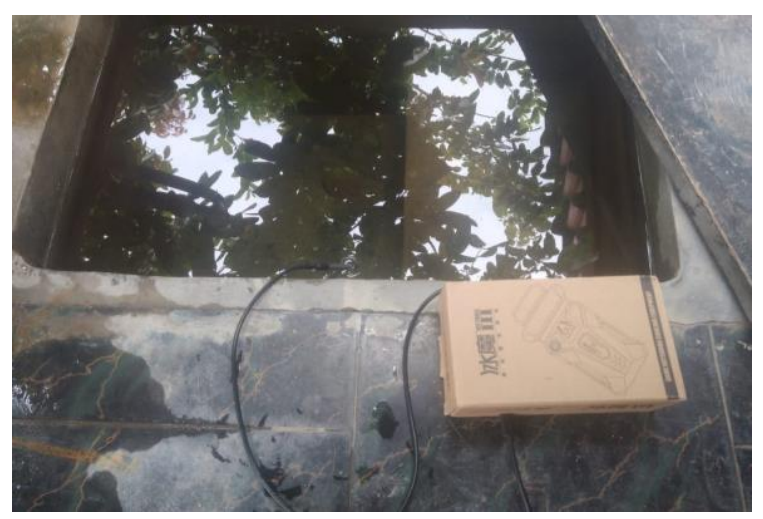

(c) Lokasi peletakan alat pada ujicoba suhu air.

Gambar 4 Kondisi uji coba perangkat.

Rumus untuk menghitung masing-masing kinerja protokol yang diuji ditunjukkan pada Persamaan 1, Persamaan 2 dan Persamaan 3. Delay adalah selang waktu antara mulai pengiriman paket data dari pengirim sampai paket diterima pada node tujuan node tujuan (Comer 2008). Delay dapat dihitung menggunakan Persamaan 1. Kategori delay diperlihatkan pada Tabel 1.

$$
\operatorname{Delay}(\mathrm{ms})=\frac{\text { Waktu paket yang dikirim }}{\text { Jumlah paket }}
$$

Packet Loss Ratio adalah persentase dari banyaknya data yang hilang pada suatu proses pengiriman data oleh transport layer atau agent layer yang lebih tinggi ke node tujuan akhir (Hanzo dan Tafazolli 2007). Packet loss dapat dihitung menggunakan Persamaan 2.

$$
\text { Packet Loss }(\%)=\frac{\text { paket yang terkirim }- \text { paket yang tercapture }}{\text { paket total tercapture }} \times 100 \%
$$

Overhead adalah persentase non-data atau header dari total data respons sebuah protokol (Falconer 2012). Protocol overhead dapat dihitung menggunakan Persamaan 3.

$$
\text { Overhead }(\%)=\frac{\text { Total Header }}{(\text { Total Header }+ \text { Total Data })} \times 100 \%
$$

\section{Lingkungan Pengembangan}

Perangkat keras yang digunakan dalam pengembangan sistem diantara lain yaitu: laptop dengan spesifikasi berikut RAM 16GB, SSD 128GB, Processor Intel i5, Windows 10; 
ESP8266 Node MCU; DS18B20 (sensor suhu air); AM2301/DHT21 (sensor suhu dan kelembaban udara). Perangkat lunak yang digunakan dalam pengembangan sistem diantara lain yaitu Arduino IDE, Visual Studio Code, XAMPP, dan NodeJS.

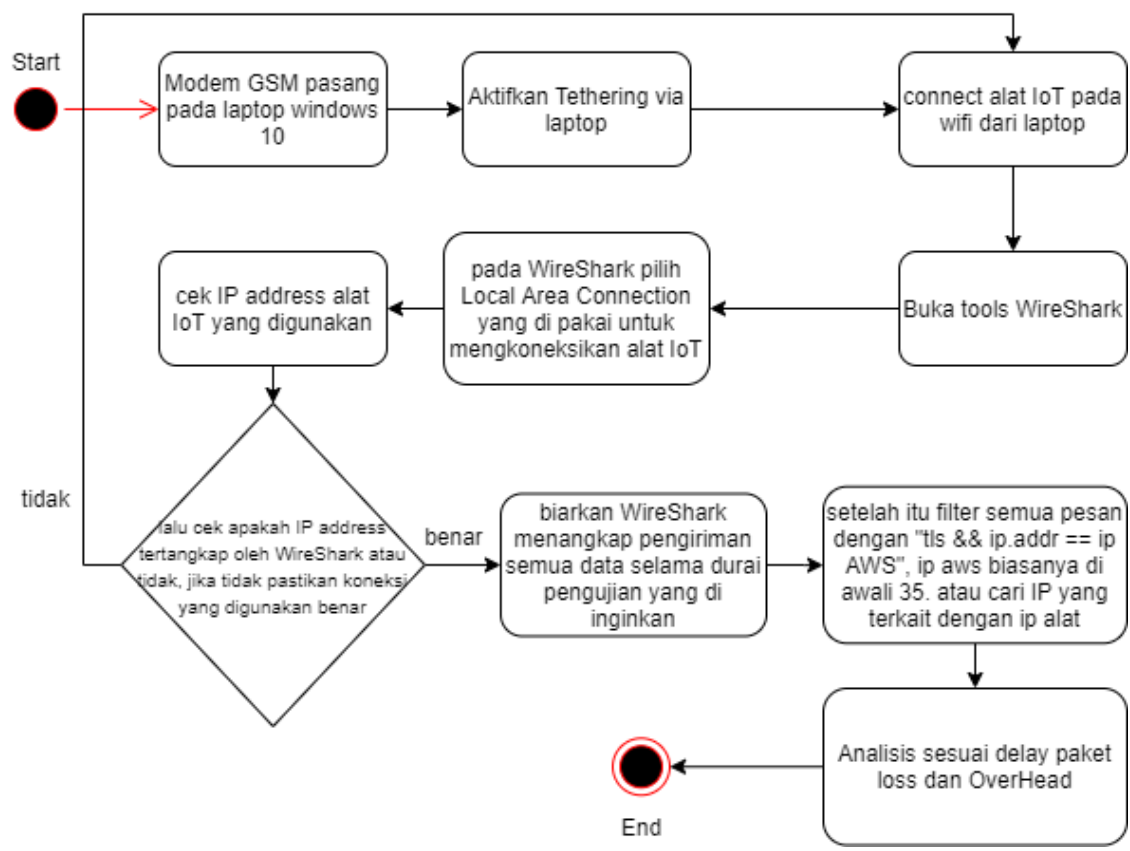

Gambar 5 Skema pengujian menggunakan WireShark.

Tabel 1 Kategori delay (ETSI 1999)

\begin{tabular}{ll}
\hline Kategori delay & Besar delay (detik) \\
\hline Sangat Buruk & Lebih dari 0.045 detik \\
Buruk & 0.03 detik sampai 0.045 \\
Bagus & 0.015 detik sampai 0.03 detik \\
Sangat Bagus & Kurang dari 0.015 detik \\
\hline
\end{tabular}

\section{HASIL DAN PEMBAHASAN}

\section{Komunikasi Data}

Skema komunikasi data penelitian ini menggunakan protokol IoT Message Queuing Telemetry Transport (MQTT). Protokol MQTT tidak menggunakan PUSH dan GET seperti IoT yang menggunakan protokol REST, namun menggunakan sistem Publish dan Subscribe. Publish digunakan untuk mengirim data ke broker IoT core dan subscribe digunakan untuk menarik data dari broker dan mengirimkan ke database yang dituju dalam penelitian ini basis data lokal. Skema Komunikasi dapat dilihat pada Gambar 6.

Semua alat yang dihubungkan ke broker harus didaftarkan terlebih dahulu pada menu things, pada saat pendaftaran alat maka AWS akan otomatis akan membuat kunci pribadi dan publik untuk things yang dibuat. Pada penelitian ini didaftarkan dua alat sebagai publisher untuk program pengiriman data. Things merupakan atribut dari sebuah alat yang sudah terdaftar, thingsname dapat juga disebut topic (topik). Setiap topik memiliki sertifikat dan kunci pribadi masing-masing untuk mengamankan proses pengiriman dan pengambilan data dari alat ke broker begitupun sebaliknya. Pada penelitian ini, satu topik digunakan untuk satu alat yaitu topik Karamba1 untuk alat IoT2 dan topik RumahTancap untuk alat IoT1.

\section{Integrasi Perangkat Keras dan Perangkat Lunak}

Pada sensor untuk akuisisi data digunakan bahasa $\mathrm{C}++$ dengan IDE Arduino dan terdapat library timer untuk mengatur jadwal pengiriman data. Pada mikrokontroler penelitian ini menggunakan pustaka pemrograman DHT dan Onewire masing-masing digunakan untuk mempermudah pembacaan nilai sensor DHT21 dan DS18B20. Pada pengkodean alat disertakan 
juga fail secret.h yang berisikan sertifikat dan kunci pribadi dari thing yang telah dibuat. Fungsi dari fail secret.h digunakan agar alat dapat berkomunikasi melalui protokol MQTT.

Data yang telah dipublikasikan dapat dicek pada bagian test yang terdapat pada AWS IoT core. Pengecekan dilakukan dengan cara memasukan nama thing pada menu Publish to topic jika data berhasil terkirim maka akan muncul data beserta waktu pengiriman seperti pada Gambar 7.

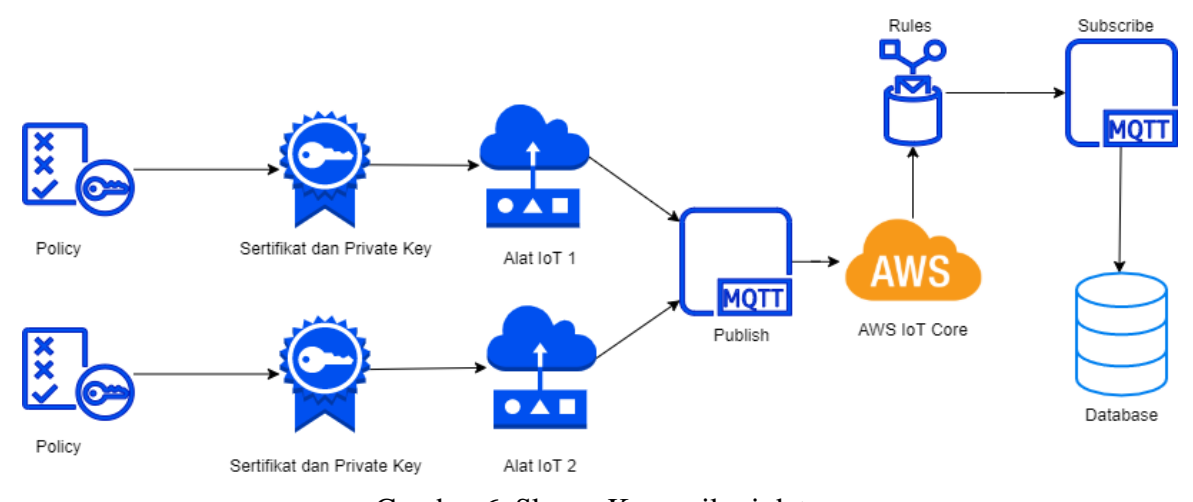

Gambar 6 Skema Komunikasi data.

Data yang telah berhasil di-publish selanjutnya dikirimkan menuju basis data yang sudah ada. Pada penelitian ini peneliti menggunakan basis data lokal. Pada API juga disertakan sertifikat sesuai topik yang dituju agar data yang telah dipublikasi dapat ditarik atau subscribe dan dimasukan ke dalam basis data. Hasil data pemantauan yang telah diambil dapat dilihat pada Gambar 8.

Gambar 8 menunjukkan bahwa fungsional pemantauan lingkungan laut telah berhasil. Pada grafik hasil dapat dilihat tidak adanya duplikasi data, setiap satu menit sensor hanya mengirimkan satu data. Pada grafik kelembaban udara mengalami kenaikan dan penurunan secara signifikan sedangkan pada suhu udara dan suhu air grafik tidak terlalu sering mengalami kenaikan atau penurunan.

\section{Analisis Pengujian Keamanan}

Pengujian keamanan dilakukan dengan metode black-box, skema pengujian dapat dilihat pada Tabel 2. Skema pengujian keamanan yang dilakukan semuanya berhasil yang mengindikasikan sistem keamanan komunikasi data berjalan sesuai dengan harapan. Pada penelitian ini tidak dilakukan pengujian keamanan untuk dekripsi data protokol saat dikirim ke broker karena sumber daya yang terbatas.

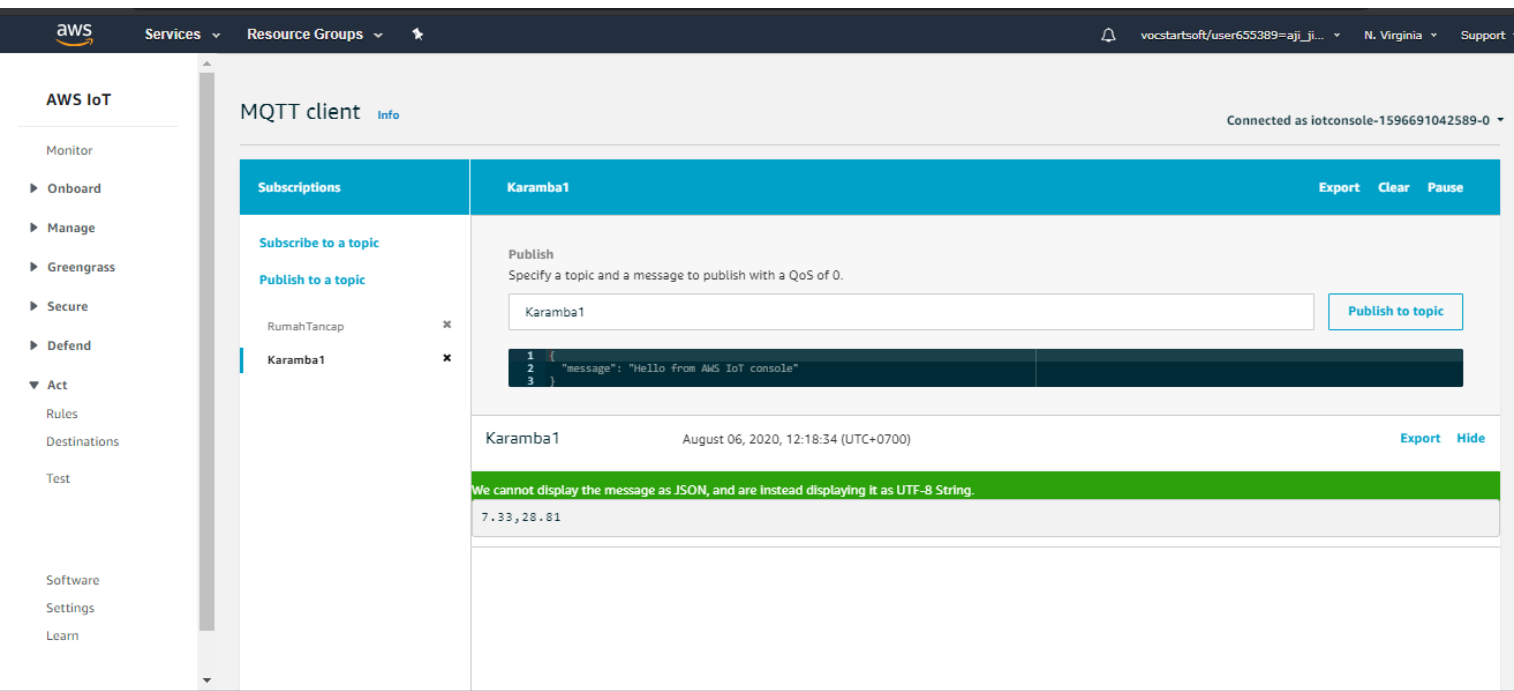

Gambar 7 Testing Publish data. 

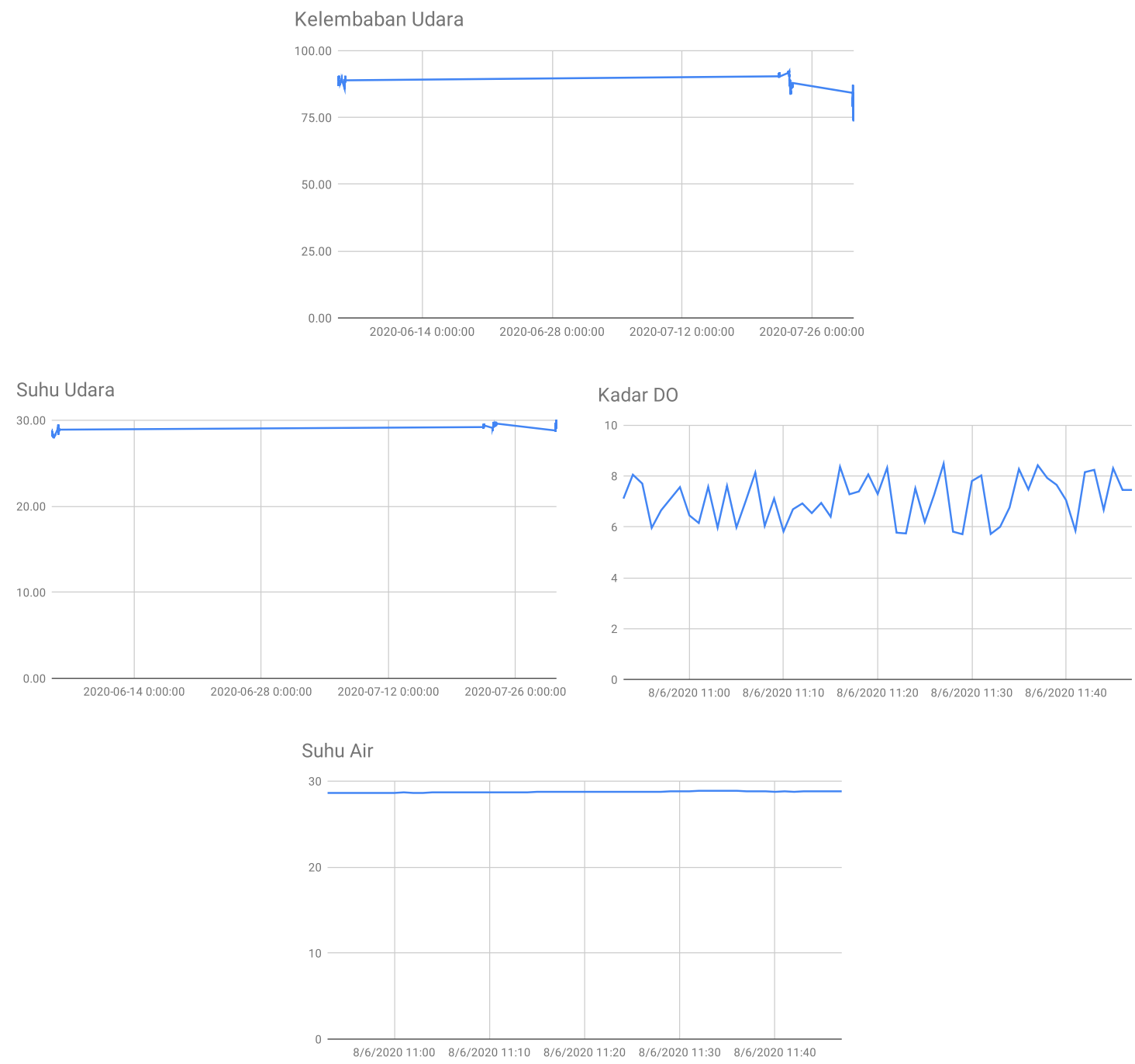

Gambar 8 Grafik hasil pemantauan lingkungan laut.

Tabel 2 Skema Pengujian Keamanan

\begin{tabular}{llll}
\hline Skema pengujian & Hasil yang diharapkan & Hasil yang didapatkan & Status \\
\hline Mengirim data dengan sertifikat dan kunci & AWS IoT Core akan & AWS IoT Core menolak & Berhasil \\
keamanan yang tidak sesuai dengan alat & menolak koneksi & koneksi & \\
$\begin{array}{l}\text { Mengirim data menggunakan nama alat yang } \\
\text { tidak terdaftar }\end{array}$ & AWS IoT Policy akan & AWS IoT Policy & Berhasil \\
Publish topik MQTT yang tidak sesuai dengan & memutuskan koneksi & memutuskan koneksi & \\
IoT Policy & $\begin{array}{l}\text { AWS IoT Policy akan } \\
\text { menolak data }\end{array}$ & $\begin{array}{l}\text { AWS IoT Policy menolak } \\
\text { Buta }\end{array}$ & \\
IoT Policy & AWS IoT Policy akan & AWS IoT Policy & \multirow{2}{*}{ Berhasil } \\
& $\begin{array}{l}\text { menghentikan } \\
\text { pengiriman data }\end{array}$ & $\begin{array}{l}\text { menghentikan pengiriman } \\
\text { data }\end{array}$ & \\
\hline
\end{tabular}

\section{Analisis Pengujian Protokol Delay}

Pada pengujian ini dilakukan selama 6 jam simulasi dengan menangkap 43200 data dengan rentang waktu 10 detik untuk setiap antar data. WireShark menangkap data yang terkirim beserta waktu kirim dan delay antara data. Protocol delay rata-rata yang didapat dari kedua alat IoT dapat dilihat pada Gambar 9.

Pada Gambar 9 dapat dilihat nilai yang besar dimiliki oleh perangkat IoT RumahTancap dengan delay 5 ms. Hasil delay keseluruhan diketagorikan sangat bagus karena memenuhi kriteria delay pada Tabel 1. Kedua alat IoT memiliki besar paket yang sama yaitu 105 bytes tetapi pada Gambar 9 kedua alat memiliki waktu delay yang berbeda $0.1 \mathrm{~ms}$. Perbedaan delay dari kedua alat disebabkan pengujian alat dilakukan pada jam yang berbeda. Pada alat IoT karamba dilakukan pengujian pada pukul 12.00 - 06.00 AM, sehingga lalu lintas pengunaan 
jaringan cenderung lebih sepi dibandingkan dengan pengujian alat IoT RumahTancap yang dilakukan pada pukul 12.00 - 06.00 PM. Perbandingan trafik data dapat dilihat pada Gambar 10 .

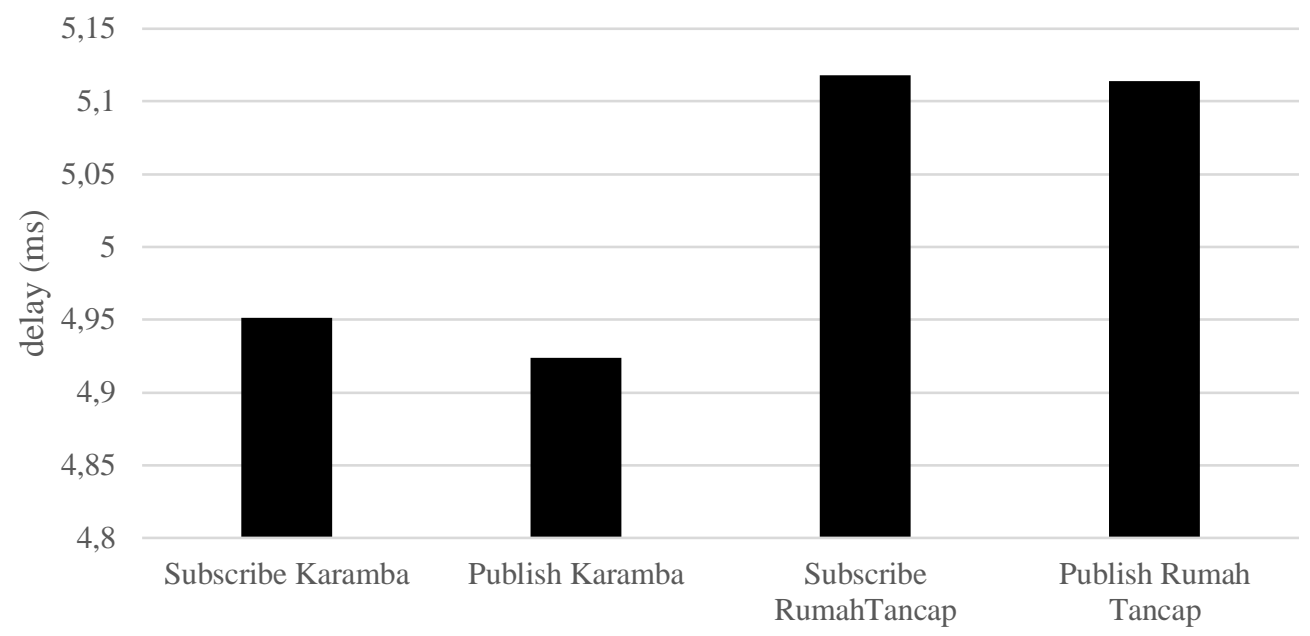

Gambar 9 Grafik Analisis pengujian protokol delay.

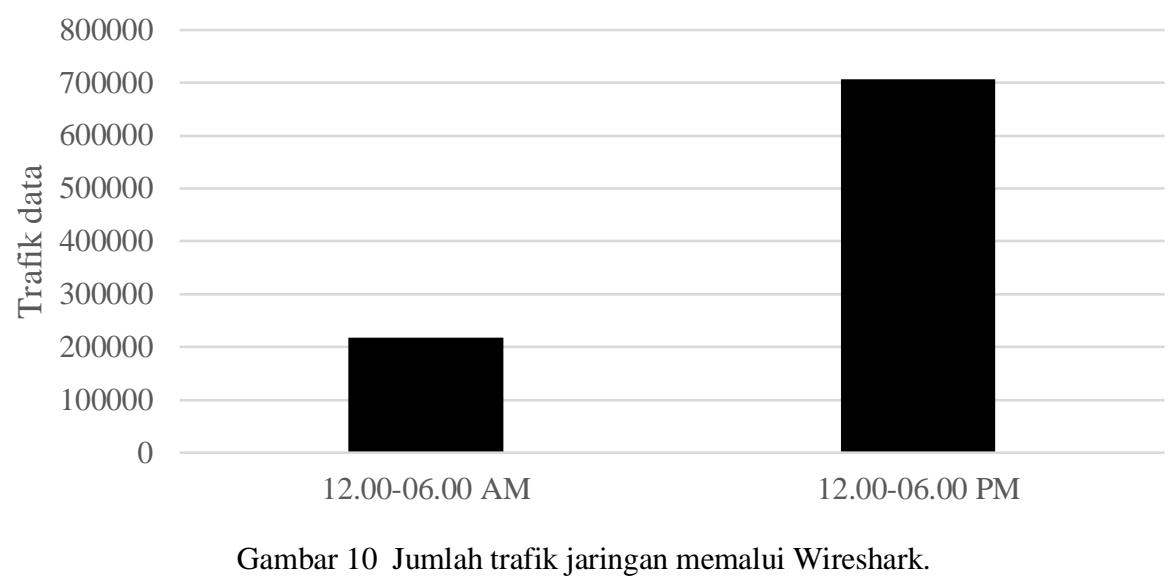

\section{Analisis Pengujian Packet Loss}

Masing-masing request protokol yang diuji menghasilkan nilai 0\% packet loss. Packet loss biasanya disebabkan oleh kepadatan jaringan, ketika paket dikirim dengan kecepatan yang lebih tinggi dari kapasitas jaringan. Pada penelitian ini, kondisi jaringan yang digunakan merupakan jaringan terbuka pada wifi publik, sehingga dalam keadaan jaringan dengan lalu lintas tinggi mendapatkan nilai 0\% packet loss merupakan hasil sangat bagus. Hal ini juga mengindikasikan tidak adanya duplikasi data yang diterima saat pengiriman dengan MQTT QoS 1.

\section{Analisis Pengujian Protokol Overhead}

Protocol overhead dilihat dari pengujian yang dilakukan dengan menangkap 43200 data. Nilai overhead dari kedua alat IoT sama seperti pada Gambar 11, dengan besar paket 105 bytes overhead yang dihasilkan yaitu sekitar $38.10 \%$. Nilai overhead yang didapat cenderung besar untuk protokol MQTT karena pengiriman data menggunakan QoS 1 dan dienkripsi dengan TLS 1.2 yang mempunyai header sebesar 46 bytes. 


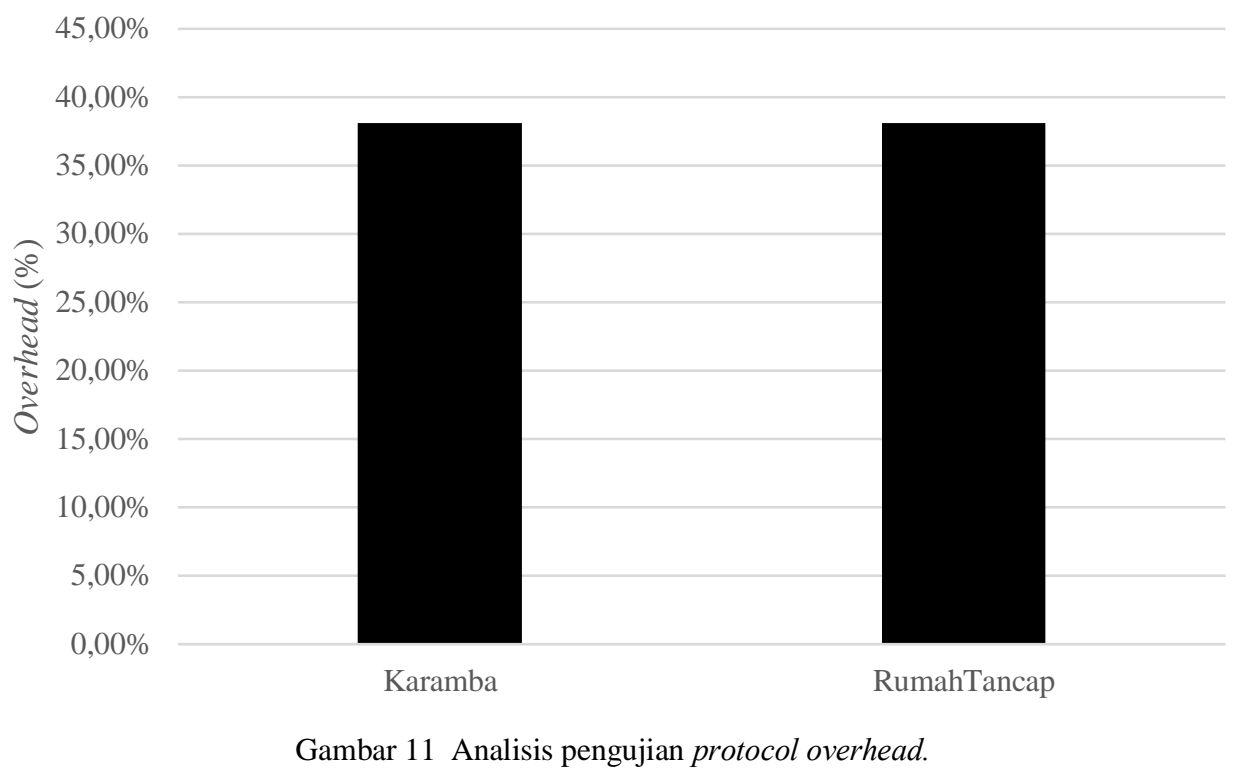

\section{SIMPULAN}

Penelitian ini telah berhasil dalam merancang dan membangun sistem pemantauan lingkungan laut dengan arsitektur internet of things (IoT). Mulai dari pengambilan data dari sensor hingga pengiriman data masuk ke basis data dan menampilkan ke dalam grafik. Selain itu, keseluruhan pengujian keamanan sistem komunikasi jaringan dengan menguji kunci pribadi dan IoT Policy menunjukkan komunikasi data IoT menggunakan layanan AWS terjamin keamanannya. Protokol MQTT 3.5 mempunyai nilai rata-rata protocol delay yang masuk kategori sangat bagus untuk semua publish semua dengan delay kurang dari 0.015 detik. Hasil pengujian menunjukan tidak ada packet loss dan duplikasi data untuk semua data yang dikirim. Nilai overhead yang didapat dari hasil pengujian cukup besar untuk protokol MQTT 3.5 karena menggunakan QoS 1 dan dienkripsi dengan protokol TLS 1.2.

\section{DAFTAR PUSTAKA}

Anderson G. 2003. A coastal management perspective on mariculture development. [internet][diakses 25 November 2019 ]. Tersedia pada marinebio.net/marinescience/ 06future/index.htm.

Budianto P, Chilmawati D. 2014. Pengaruh Chlorella SP. Dari Hasil Pencucian Bibit Sel Yang Berbeda Dalam Feeding Regimes Terhadap Pertumbuhan Dan Kelulushidupan Larva Kerapu Macan (Epinephelus Fuscoguttatus). Journal of Aquaculture Management and Technology, 3(4), 289-298.

Comer DE. 2008. Computer Networks and Internets Ed ke-5. New Jersey (NJ): Pearson Education.

Effendi I. 2005. Riset Terapan Pengembangan Sea Farming di Kepulauan Seribu. [internet][diakses 9 November 2019]. Tersedia pada http://www.pksplipb.or.id.

ETSI. 1999. Telecommunications and Internet Protocol Harmonization Over Networks (TIPHON); General aspects of Quality of Service [Internet]. [diakses 2020 Apr 25]. Tersedia pada: etsi.org/deliver/etsi_tr/101300_101399/101329/02.01.01_60/tr_101 329v020101p.pdf

Hanzo L, Tafazolli R. 2007. A survey of QoS routing solutions for mobile ad hoc networks. IEEE Communications Surveys \& Tutorials. 9(2): 50-70.

Mulyono S, Haviana SF. 2018. Implementasi MQTT untuk Pemantauan Suhu dan Kelembaban pada Laboratorium. TRANSISTOR Elektro dan Informatika 3(3):140-4.

Nontji A. 2005. Laut Nusantara (edisi revisi). Jakarta (ID): Djambatan.

Suminto, Hirayama K. 1996. Effect of Bacteria Coexistence on the Growth of a Marine Diatome Chaetoceros gracilis. Fisheries Science 62(1): 40-43. 
Sutamihardja RT. 1987. Kualitas Pencemaran Lingkungan. Sekolah Pascasarjana Jurusan Pengelolaan Sumberdaya Alam dan Lingkungan. Bahan Kuliah: Institut Pertanian Bogor. Uckelmann D, Harrison M, Michahelles F. 2011. Architecting the Internet of Things. London (UK): Springer Heidelberg Dordrecht. 